\title{
FROM PRODUCER TO CONSUMER: RELATIONS BETWEEN PRICES OF SELECTED PRODUCTS IN THE AGRI-FOOD MARKET
}

\author{
Agnieszka Tłuczak ${ }^{\varpi}$ \\ University of Opole, Poland
}

\begin{abstract}
The food supply chain is characterized by a large diversity of entities comprising it, and combines actions taken at different levels, starting with the producer and ending with the consumer. The primary aim of an efficient functioning of the food supply chain is to ensure buyer satisfaction while providing profits to companies participating in product flows. Changes occurring in agricultural production, often cyclical, are echoed at each stage of the supply chain. This phenomenon is visible in changes to price levels and in dependencies between price levels at individual stages of the chain. Prices are the most dynamic element of the market; price volatility and transmission has always been the subject of theoretical considerations and empirical market analyses. Hence, the main purpose of this paper was to investigate the occurrence of milk and poultry price transmission in the supply chain. This analysis will cover the study of existing relationships between prices of selected agri-food products at individual stages of the supply chain, and will determine their direction. In addition, the analyses will be supplemented with the assessment of price growth in real and nominal terms at individual stages of the supply chain. The occurrence of transmission of price signals in the study of these relationships will be checked with the Granger causality test and VAR models which do not require the model to be compliant with the theory of economics. The period covered by these analyses is $2010-2017$.
\end{abstract}

Keywords: agri-food market, Granger test, price transmission

\section{INTRODUCTION}

The agri-food market follows market mechanisms. Additionally, changes in the economic system drive changes in market conditions of agricultural production. The study of price volatility and transmission of price signals in the food supply chain is a complex issue because agricultural raw materials are usually processed and take different forms in the process of adjustment to consumer requirements. In addition, high variability of prices and market conditions is caused by the fact that agricultural production is cyclical and largely depends on atmospheric conditions.

The food supply chain, agriculture, agri-food industry and distribution contribute more than $5 \%$ to value added generated in Europe and account for $7 \%$ of jobs (Tłuczak, 2016). With a share of ca. $9 \%$ in value, Poland is the sixth largest food producer in the European Union. The sales of the agri-food processing sector in Poland account for over $6 \%$ of GDP. In turn, the Polish food sector contributes over $20 \%$ to sales of the entire domestic industry. It consists of ca. 16 thousand companies employing 402 thousand people, i.e. ca. $16 \%$ of those employed in the domestic industry. Meat processing has the biggest share in the food industry (ca. 22\%). Compared to the entire EU food industry, the Polish food industry has a remarkable share of the production of milk and dairy products $(8.2 \%)$, ranking Poland fourth in the

\footnotetext{
$\bowtie$ Agnieszka Tłuczak, PhD, Department of Econometrics and Quantitative Methods, University of Opole, Ozimska 46a St., 46-058 Opole, Poland, e-mail: atluczak@uni.opole.pl, https://orcid.org/0000-0001-6217-8822
} 
EU (MRiRW, 2017). On the other hand, the largest part the Polish food industry is the meat sector; meat, offal and meat products are among the main export goods in the group of agri-food products (Piwowar, 2014).

Any disruption to the circulation of products in the food supply chain can have serious economic and social consequences for farmers, cooperatives and rural areas. In recent years, price fluctuations (both in prices paid to farmers and in those paid by consumers) have highlighted the imbalances in the supply chain. This poses a serious threat to that sector's sustainability, particularly as regards agriculture. The main causes of this imbalance are increased globalization and concentration, especially in the retail sector. The main effect of this imbalance is a very strong downward pressure on prices paid to farmers. Farmers are not in a position to cover production costs on their own, nor do they have the money to invest, leading to abandonment and long delays in investment and innovation. The latest Eurostat data on farmers' income in 2009 show a decrease by $11.6 \%$ at EU level (CAP by 2020; Tłuczak, 2016).

Exploiting the full potential of food supply chain is not an easy task due to the complexity of the network and of existing relations between chain members (Szymańska, 2018). Supply chain participants differ in size and act as competitors, suppliers and customers (Kawecka and Gębarowski, 2018). Globalization and the establishment of the single European market is what drives changes in the logistics policies of participants to the food supply chain. Moreover, international operators are increasingly competing in the various sectors of the food chain (Motowidlak and Fajczak-Kowalska, 2010).

\section{RESEARCH METHODOLOGY}

The main objective of research was to identify causal relationships between prices which occur on milk and poultry market (separately) in different links of the supply chain. The following stages were identified in the study: purchase centers for agricultural products; agrifood processors; and retail points of sale. The study analyzed the price transmission signals between particular stages of the supply chain (purchase, production and trade) in the market for poultry meat and in the milk market. The Granger causality test, which is based on the autoregressive vector (VAR) models (Kusidel, 2000;
Tłuczak, 2011a), was used ${ }^{1}$ to verify the hypothesis that causal relationships exist between the variables.

First of all, this paper will focus on the case where Granger causality can be thought of as an idea of finding causal relations using structural econometric models. A simple structural econometric model of the form can be used (Kusidel, 2000; Charemza and Deadman, 1997):

$$
\begin{gathered}
y_{t}=\alpha_{0}+\alpha_{1} y_{t-1}+\ldots+\alpha_{p} y_{t-p}+\varepsilon_{t} \\
y_{t}=\alpha_{0}+\alpha_{1} y_{t-1}+\ldots+\alpha_{p} y_{t-p}+\beta_{1} x_{t-1}+\beta_{2} x_{t-2}+ \\
+\ldots+\beta_{p} x_{t-p}+\eta_{t}
\end{gathered}
$$

where:

$x_{\mathrm{t}}$-variable $X ; y_{\mathrm{t}}$ - variable $Y ; p$ - lag order.

Testing the hypothesis ${ }^{2}$ about causative relationships comes down to comparing the variance of the components of residual models 1 and 2 :

$$
H_{0}: \sigma^{2}\left(\varepsilon_{t}\right)=\sigma^{2}\left(\eta_{t}\right) ; H_{1}: \sigma^{2}\left(\varepsilon_{t}\right) \neq \sigma^{2}\left(\eta_{t}\right)
$$

According to the Wald criterion, in this Granger test, the test statistic takes the following form (Tłuczak, 2011b):

$$
F=\frac{n \cdot\left(s^{2}\left(\varepsilon_{t}\right)-s^{2}\left(\eta_{t}\right)\right)}{s^{2}\left(\varepsilon_{t}\right)}
$$

The statistic has a chi-squared distribution $\chi_{\alpha}^{2}(p)$, where $p$ is the lag order.

The variables should be checked for stationarity before applying the Granger test. If the variables are not stationary, the Granger test does not work correctly (Przekota and Lisowska, 2013; Tłuczak, 2011a). Among the many tests proposed in the literature for testing

\footnotetext{
${ }^{1}$ Granger causality is a statistical concept of causality based on prediction. According to Granger causality, if the signal $X_{1}$ "Granger-causes" (or "G-causes") the signal $X_{2}$, then past values of $X_{1}$ should contain information that helps predict $X_{2}$ above and beyond the information contained in past values of $X_{2}$ alone. Its mathematical formulation is based on linear regression modeling of stochastic processes (Granger, 1969). More complex extensions to nonlinear cases exist, however they are often more difficult to apply in practice.

${ }^{2}$ The null hypothesis for the test is that lagged $x$-values do not explain the variation in $\mathrm{y}$. In other words, it assumes that $x(t)$ does not Granger-cause $y(t)$. Theoretically, the Granger test can be run to find out if two variables are related at an instantaneous moment in time.
} 
stationarity, the popular ADF test was used ${ }^{3}$. In this test, the null hypothesis is that the time series is nonstationary due to the presence of a unit root $\left(H_{0}: \delta=0\right)$. The alternative hypothesis assumes that the time series is stationary $\left(H_{1}: \delta<0\right)$. A modified version of the test (ADF) is often used and is given as follows (Tluczak, 2011b):

$$
\Delta y_{t}=\mu+\delta y_{t-1}+\sum_{i=1}^{k} \delta \Delta y_{t-\mathrm{i}}+e_{t}
$$

or

$$
\Delta y_{t}=\delta y_{t-1}+\sum_{i=1}^{k} \delta_{i} \Delta y_{t-i}+e_{t}
$$

The decision on whether or not to reject the null hypothesis is based on the DF statistics calculated using the following quotient (Borzyszkowska, 2007):

$$
D F=\frac{\delta}{S(\delta)}
$$

\section{CAUSES AND EFFECTS - TRANSMISSION OF PRICE SIGNALS}

Empirical data used in this study covers the period from January 2010 to May 2018, and includes: average monthly nominal prices of milk in PLN per liter purchased $\left(y_{1}\right)$; producer prices of fresh butter with $82.5 \%$ fat content per $200 \mathrm{~g}\left(y_{2}\right)$; retail prices of fresh butter with $82.5 \%$ fat content per $200 \mathrm{~g}\left(y_{3}\right)$; buying-in prices of slaughter poultry in PLN per $\mathrm{kg}\left(y_{4}\right)$; producer prices of eviscerated chicken in PLN per $\mathrm{kg}\left(y_{5}\right)$; and retail prices of eviscerated chicken in PLN per kg $\left(y_{6}\right)$ in Poland. The data is based on information provided by the Central Statistical Office. Fig. 1 presents the price volatility of products; selected descriptive statistics are shown in Table 1.

In 2010-2018, the milk and butter markets developed in a similar way, with two turning points: January 2014 and May 2016, marking a reversal of the trend. Early 2014 witnessed a collapse of the market, and a decline in prices was observed over the next two years. In $1 \mathrm{H} \mathrm{2016}$, the situation in the domestic milk was primarily driven by the deepening downturn and drop in prices in the global market, caused by the reduction of demand

${ }^{3}$ The lack of stationarity can provide misleading results of analysis. In this analysis the Granger causality in narrow sense was considered.
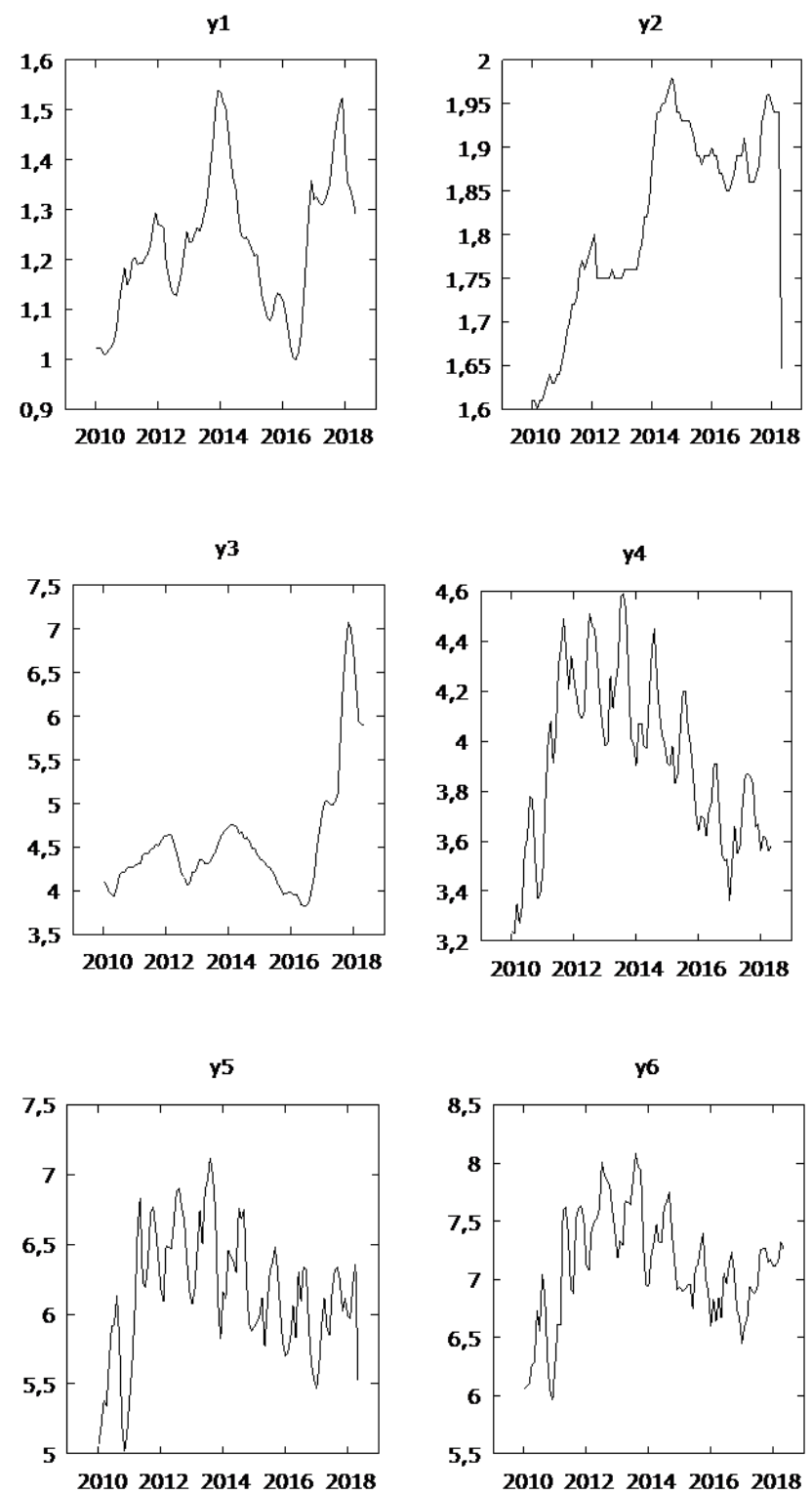

Fig. 1. Evolution of volatility in variables $y_{1}-y_{6}$ over the period 2010-2018

Source: own elaboration based on Statistics Poland.

from developing countries (mainly China) in a context of high supply from, and increase in stocks of, the largest exporters. To balance the global demand and supply, the prices needed to drop, reaching unprecedented levels in 1H 2014. An additional factor destabilizing the domestic market was the Russian embargo on food imports from the European Union, including Poland. 
Table 1. Descriptive statistics for logarithmic increases in meat prices

\begin{tabular}{ccccc}
\hline Variable & Mean & $\begin{array}{c}\text { Variation } \\
\text { coefficient }\end{array}$ & Skewness & Kurtosis \\
\hline$y_{1}$ & 1.230 & 0.114 & 0.334 & -0.512 \\
$y_{2}$ & 1.817 & 0.059 & -0.436 & -0.958 \\
$y_{3}$ & 4.568 & 0.151 & 2.059 & 4.057 \\
$y_{4}$ & 3.920 & 0.085 & -0.023 & -0.766 \\
$y_{5}$ & 6.147 & 0.073 & -0.259 & -0.185 \\
$y_{6}$ & 7.110 & 0.066 & -0.301 & -0.214 \\
\hline
\end{tabular}

Source: own elaboration based on Statistics Poland.

The analysis of the relation between producer prices of fresh butter with $82.5 \%$ fat content and milk buyingin prices reveals a volatility level of $22 \%$. Nevertheless, the prices of fresh butter with $82.5 \%$ fat content are on average nearly $50 \%$ higher than milk buying-in prices. From the perspective of agricultural producers, the most disadvantageous ratio between these prices was recorded in July 2016; at that time, $1 \mathrm{~kg}$ of fresh butter with $82.5 \%$ fat content was equivalent to 14 liters of milk at buying-in prices. The situation in the market for poultry meat is definitely different. At each stage (buying-in, producer, and retail sales), the situation changes rapidly, without translating into a high coefficient of variation across the study period. Buying-in prices, producer prices and retail outlet prices followed the same trend. At the same time, retail price per kg of eviscerated chicken is almost twice as high as the buying-in price of live poultry.

Two product groups were considered: 1) milk and fresh butter with $82.5 \%$ fat content; 2) poultry and eviscerated chicken. For these products, the transmission of prices between supply chain stages was considered separately within each group. The Granger test was used to establish the directions of dependence, which was considered for the of 1,2,3, 4 delay order.

In the case of markets covered by this analysis, it is necessary to determine whether the price signals flow from buying-in prices through to processing plant prices and retail prices, or in the opposite direction, or whether the dependencies are bidirectional in nature.
The use of Granger test requires the variables to be stationary. The extended Dickey-Fuller test ${ }^{4}$ was used to check for stationarity. This resulted in rejecting the null hypothesis and retaining the alternative hypothesis that the time series under consideration is stationary ${ }^{5}$.

The analysis of findings brought the following conclusions:

- changes in buying-in milk prices are the reason (in the Granger sense) for changes in producer prices of fresh butter with $82.5 \%$ fat content (at $k=3$ );

- changes in producer prices of fresh butter with $82.5 \%$ fat content are the reason (in the Granger sense) for changes in retail prices of fresh butter with $82.5 \%$ fat content (at $k=1.2$ );

- changes in retail prices of fresh butter with $82.5 \%$ fat content are the reason (in the Granger sense) for changes in producer prices of fresh butter with $82.5 \%$ fat content (at $k=1.2$ );

- changes in buying-in prices of slaughter poultry are the reason (in the Granger sense) for changes in producer prices of eviscerated chicken (at $k=2.3$ );

- changes in producer prices of eviscerated chicken are the reason (in the Granger sense) for changes in retail prices of eviscerated chicken (at $k=3$ );

- changes in retail prices of eviscerated chicken are the reason (in the Granger sense) for changes in retail prices of poultry slaughter at point of purchase (at $k=1.4$ ).

Cross-causality exists between producer and retail prices of fresh butter with fat content of $82.5 \%$. This means that the respective prices are each other's causes and effects at the same time.

The Granger causality test is the right tool to identify the mechanism for the transfer of price signals between different stages of the supply chain. As shown by the results of the Granger causality test, price signals predominantly move upwards in marketing channels, starting

${ }^{4}$ Calculations were carried out for logarithmic increments calculated according to the formula $r_{t}=\frac{\ln P_{t}}{P_{t-1}}$, where $P_{t}$ is the price at time $t$, and $P_{t-1}$ is the price of goods in the previous period. As numerous studies have shown, data characterized by a high frequency exhibits high volatility, and the price series are nonstationary. When logarithmic price increments are calculated, the series considered usually become stationary (Syczewska, 2004).

${ }^{5}$ Calculations were carried out in GRETL. 
from buying-in centers, through to producers and retail sales points. The study revealed a unidirectional downward flow of signals, from retail prices of eviscerated chickens to buying-in prices of slaughter poultry. It is also clear that the signals are transmitted with different lags (from 1 to 4 ), and market reactions are not always immediate.

\section{CONCLUSIONS}

Changes in the agri-food market are reflected in the functioning of the supply chain of agri-food products. The nature of these changes largely depends on the production and economic situation of sectors composing the supply chain. In the case of food products, the changes depend on factors such as: large fluctuations in the dynamics of plant and animal production from one year to another; a consistent increase in prices of productive inputs; and the changing economic situation in global markets. The pace of production growth in operators active in the food supply chain is influenced by structural and transitory factors which may slow down or accelerate it (Tłuczak, 2016).

Hence, the main purpose of this paper was to investigate the occurrence of milk and poultry price transmission in the supply chain. Appropriate models were built and estimated for particular pairs of variables in order to answer the question whether changes in prices of a product are the reason (in the Granger sense). The findings revealed the existence of causal relationships (in the Granger sense) in the milk, butter and poultry markets in Poland in 2010-2018. The time series covered by this study proved to be stationary, and therefore it was not necessary to determine the respective growth rates. When adequately lagged, price categories of product covered by this analysis provide a better price forecast. The response of retail prices to price changes at processing plant level did not differ between the products. In each case, a relationship was identified between producer price trends and their impact on retail price trends. The fastest response was observed for fresh butter with $82.5 \%$ fat content.

\section{SOURCE OF FINANCING}

Statutory research of the University of Opole, Faculty of Economics.

\section{REFERENCES}

Borzyszkowska, M. (2007) Analiza empiryczna wybranych zmiennych wchodzących w skład funkcji popytu na pieniądz [Empirical analysis of selected variables that are part of the money demand function]. In: Dynamiczne Modele Ekonometryczne, X Ogólnopolskie Seminarium Naukowe, Uniwersytet Mikołaja Kopernika w Toruniu [Dynamic Econometric Models, 10th National Scientific Seminar, Nikolaus Copernicus University in Toruń]. Retrieved from: http://www.dem.umk.pl/DME/2007/borzyszkowska.pdf [in Polish].

Charemza, W., Deadman, D. (1997). Nowa ekonometria [New econometrics]. Warszawa: PWE [in Polish].

Granger, C. W. J. (1969). Investigating Causal Relations by Econometric Models and Cross-spectral Methods. Econometrica, 37(3), 424-438.

Kawecka, A., Gębarowski, M. (2018). Short Food Supply Chains - Benefits for Consumers and Food Producers. J. Agribus. Rural Dev., 3(37), 459-466.

Kusideł, E. (2000). Modele wektorowo-autoregresyjne VAR. Metodologia i zastosowania, [Vector-autoregressive VAR models. Methodology and applications]. Olsztyn: Absolwent [in Polish].

Motowidlak, U., Fajczak-Kowalska, A. (2010). Wartość dodana w łańcuchu dostaw żywności [Added Value in Delivery Chain of Food]. Zesz. Nauk. SGGW Warsz. Probl. Roln. Świat., 10 (XXV), 2, 91-99 [in Polish].

MRiRW (2017). Przetwórstwo rolno-spożywcze w Polsce. Wiadomości Rolnicze Polska. [Agri-food processing in Poland. Agricultural News Poland]. Retrieved from: https:// www.wrp.pl/przetworstwo-rolno-spozywcze-polsce/ [in Polish].

Piwowar, A. (2014). Jaka jest skala eksportu polskiego mięsa? [What is the scale of Polish meat exports]. Gazeta Fin., 14-20 listopada [in Polish].

Przekota, G., Lisowska, A. (2013). Powiązania kursu walutowego i wymiany handlowej Polski [Relationship between exchange rate and Polish trade]. Zesz. Nauk. UPH Siedl., 99 [in Polish].

Syczewska, E. (2004). Wpływ agregacji danych na mierniki długiej pamięci na przykładzie kursów walutowych [The impact of data aggregation on long memory meters on the example of exchange rates]. Warszawa: SGH [in Polish].

Szymańska, E. (2018). Functioning of the Supply Chain of Pork in Poland. J. Agribus. Rural Dev, 37(3), 555-563.

Thuczak, A. (2011a). Wpływ cen skupu żywca na ceny detaliczne mięsa [The impact of livestock purchase prices on retail meat prices]. Metod. Iloś. Bad. Ekon., 12(2), 373380 [in Polish]. 
Tłuczak, A. (2019). From producer to consumer. relations between prices of selected products in the agri-food market. J. Agribus. Rural Dev., 3(53), 267-272. http://dx.doi.org/10.17306/J.JARD.2019.01180

Thuczak, A. (2011b). Wpływ czynników pogodowych na wielkość i ceny skupu pszenicy i żyta w Polsce [Impact of weather conditions on the volume and prices of wheat and rye purchases in Poland]. Woda Środ. Obsz. Wiej., 11(4), 217-227 [in Polish].

Tłuczak, A. (2016). Analiza zmian cen w łańcuchach dostaw żywności na przykładzie rynku mięsa wołowego w Polsce [Analysis of price changes in food supply chains on the example of the beef market in Poland]. Zesz. Nauk. SGGW Warsz. Ekon. Org. Logis., 1(1), 85-93 [in Polish].
WPR do 2020 r.: sprostać wyzwaniom przyszłości związanym z żywnością, zasobami naturalnymi oraz aspektami terytorialnymi (2010) [CAP 2020: meet the challenges of the future related to food, natural resources and territorial aspects]. Komunikat Komisji Do Parlamentu Europejskiego, Rady Europejskiego Komitetu Ekonomiczno-Społecznego I Komitetu Regionów, Bruksela, dnia 18.11.2010 $\operatorname{KOM}(2010) 672$ [in Polish]. 